\title{
Spread of common native and invasive grasses and ruderal trees following anthropogenic disturbances in a tropical dry forest
}

\author{
Xavier A. Jaime ${ }^{1,4^{*}}$, Skip J. Van Bloem², Frank H. Koch ${ }^{3}$ and Stacy A. C. Nelson ${ }^{4}$
}

\begin{abstract}
Introduction: A fundamental challenge to the integrity of tropical dry forest ecosystems is the invasion of nonnative grass species. These grasses compete for resources and fuel anthropogenic wildfires. In 2012, a bulldozer from the Puerto Rico Electric Power Authority cleared a 570-m trail from a state road into a mature dry forest section of Guánica Forest to control a wildfire. We monitored colonization by a non-native invasive grass (Megathyrsus maximus), a highly invasive tree (Leucaena leucocephala), and a native grass (Uniola virgata), as well as natural regeneration, along the bulldozer trail. We determined whether bulldozing facilitated colonization by these species into the forest and the extent of spread.

Results: Distance from propagule source and temporal variations strongly influenced colonization by our three focal species. Megathyrsus maximus invaded along the trail from source populations by the state road. The establishment of new colonies of M. maximus seedlings went as far as $570 \mathrm{~m}$ inside the forest (i.e., at the end of the bulldozer trail), but we found most new colonies within $270 \mathrm{~m}$ of the road. Leucaena leucocephala exhibited a similar spreading pattern. Before disturbance, Uniola virgata was distributed widely across the forest, but the highest densities were found in areas near the latter portion (> $401 \mathrm{~m}$ ) of the bulldozer trail. Subsequently, the species formed new clumps along more than half of the trail (250 to $570 \mathrm{~m}$ ), apparently colonizing from undisturbed patches nearby.

Conclusions: Bulldozing facilitated the invasion of non-native vegetation. The projected community assemblage will be more fire-prone than before since $M$. maximus carries fire across the landscape better than $U$. virgata, emphasizing the capacity of invasive plant colonization to alter local ecological processes after only a single wildfire and bulldoze event. Our results provide a valuable baseline for short-term vegetation response to anthropogenic disturbances in tropical semi-deciduous dry forests.
\end{abstract}

Keywords: Tropical dry forest, Grass invasions, Bulldozing, Wildfire, Leucaena leucocephala, Megathyrsus (Panicum) maximus, Uniola virgata

\footnotetext{
* Correspondence: x_jaime_19@tamu.edu

'Department of Ecosystem Science and Management, Texas A\&M University,

2138 TAMU, College Station, TX 77843-2138, USA

${ }^{4}$ Center for Geospatial Analytics, Department of Forestry and Environmental

Resources, North Carolina State University, Raleigh, NC 27695, USA

Full list of author information is available at the end of the article
} 


\section{Introduction}

An important goal of invasion ecology is to understand how biological invasions are driven by anthropogenic alteration of native habitats (Vitousek et al. 1996; Wilcove et al. 1998; Mack and D'Antonio 2003; Lockwood et al. 2007; Gooden and French 2014). Even though some forests are capable of absorbing human activities that mimic natural disturbances, the frequency and intensity of those disturbances can have major impacts on ecosystem function (Molina Colón and Lugo 2006; Van Bloem et al. 2005). Anthropogenic changes to ecosystems can shift community assemblages during regeneration, triggering environmental changes that influence above- and belowground dynamics (Ammondt and Litton 2012). These changes can contribute to the establishment of invasive species in the short term, but if further disturbances are minimal, the spread of an invader within an affected ecosystem may ultimately decline over the long term (Rew and Johnson 2010). On the other hand, there is limited information about overlapping effects of niche alteration and plant invasion on native communities (Didham et al. 2007; Gooden and French 2014). Thus, it is difficult to ascertain whether drivers of habitat modification might interact in such a way as to further facilitate invasions during post-disturbance recovery of the system (Didham et al. 2007).

In tropical dry forest systems (Janzen 1988), grass intrusion and other habitat modifications driven by anthropogenic disturbance can yield widely different outcomes depending on the degree of degradation and frequency of perturbation. Disturbance can negatively influence resource acquisition and use by native trees and saplings (Hoffmann et al. 2009), increase fuel loads for wildfires, and alter understory vegetation structure (Rojas-Sandoval and Acevedo-Rodríguez 2014; Hoffmann et al. 2012; Cordell and Sandquist 2008; Brooks et al. 2004). The process of natural regeneration after a disturbance relies on the local plant community's ability to survive in a resource-depleted ecosystem, and amidst competition from potential invasive species, before the system can regain its optimal functionality (Ammondt and Litton 2012; Rew and Johnson 2010). If implemented according to an adaptive ecosystem management framework, human-facilitated efforts to restore ecological function can provide needed support when natural regeneration seems insufficient to restore and sustain the health, productivity, and biodiversity of the system (Griscom and Ashton 2011). For instance, when a fireprone invasive grass species is highly abundant, it intensifies the frequency of wildfires in invaded dry forests (Thaxton et al. 2012a; Hoffmann et al. 2012). Under these circumstances, management recommendations usually focus on reducing fuel loads (Janzen 1988) with prescribed fires in combination with the restoration of tree canopy cover (Brooks and Lusk 2008; Francis and Parrotta 2006). Unfortunately, additional anthropogenic disturbances (e.g., bulldozing), even those with the specific motive of creating fire breaks, may actually exacerbate the risk of wildfires in the system by facilitating the further introduction and spread of fire-prone invasive grasses (Chinea 2002). Effective dry forest management for species diversity between coexisting invasive and native plant species in Puerto Rico must adopt a comparative co-occurrence approach (Daehler 2003; Padmanaba and Sheil 2014) for better understanding of the rates and patterns of spread of these species after such disturbances (Lugo and Brandeis 2005). In this study, we focused on three important plant species in Puerto Rican dry forests: a non-native grass, Megathyrsus maximus (Jacq.) B.K. Simon \& S.W.L. Jacobs; a native grass, Uniola virgata (Poir.) Griseb; and a ruderal and potentially invasive leguminous tree, Leucaena leucocephala (Lam.) de Wit.

Megathyrsus maximus (Guinea grass) is a fire-prone invasive grass that was introduced to Puerto Rico in the late 1800 s for cattle forage and subsequently spread into the forest (Monsegur-Rivera 2009). Megathyrsus maximus is a warm-season, tropical $\mathrm{C}_{4}$ African grass capable of suppressing and displacing native vegetation on fertile soils. This species is fully capable of surviving fires and subsequently out-competing native vegetation in lowland landscapes after a significant disturbance (D'Antonio and Vitousek 1992; Pivello et al. 1999; Ammondt et al. 2013). Veldman and Putz (2010) studied the long-distance dispersal of M. maximus in lowland Bolivia and noted suitable conditions for this species to colonize logged forests, including shade tolerance (10\% full sunlight; $38 \%$ survival). Logging trucks were responsible for $97 \%$ of seed dispersal (i.e., 1270 seeds $/ \mathrm{m}^{2}$ ) along roadsides, and Veldman and Putz (2010) concluded that bulldozing facilitates the spread of propagules into the forest.

Uniola virgata is a native perennial $\mathrm{C}_{4}$ grass commonly found on dry coastal limestone slopes and hills, forming dense clumps or bunches with dead leaves curled around the base of the stems (Monsegur-Rivera 2009). The species is most common in locations with little canopy cover, but native woody shrubs and scattered trees are typically also found in these locations (Thaxton et al. 2012b; Garcia-Cancel 2013; Jaime, personal observation). The ecology of $U$. virgata is still poorly known beyond its local-scale spatial distribution pattern and rate of biomass accumulation, as well as qualitative observations regarding its limited ability to resprout from rhizomes after a fire (Thaxton et al. 2012b).

Leucaena leucocephala (commonly known as the lead tree, jumbay, tantan, white popinac or zarcilla) was introduced to Puerto Rico in the 1700s from Mexico by Spanish settlers. In terms of categories defined by Richardson et al. (2000) with respect to alien plant 
species, L. leucocephala can be considered a naturalized species because it is capable of sustaining a stable population over many life cycles with or without anthropogenic intervention. However, depending on habitat conditions, it has the potential to behave as an invasive species colonizing natural and semi-natural ecosystems (Richardson et al. 2000). Historically in Puerto Rico, L. leucocephala has been one of the most prominent ruderal species and is usually among the first plant species to colonize disturbed lands such as abandoned agricultural fields, previously cleared forests, and along roads (Christen and Matlack 2006; Van Bloem et al. 2004). To some extent, it can survive lowintensity fires in tropical dry forest ecosystems (Wolfe and Van Bloem 2012). It can grow on most soils in semi-natural, disturbed, eroded, and degraded habitats, tolerates an extensive range of precipitation (500$3500 \mathrm{~mm}$ ), and is capable of surviving a lengthy (68 months) dry season (Francis and Lowe 2000). A shade-intolerant species, L. leucocephala thrives in open canopy, competing with grasses and weeds during early growth (Parrotta 2000). However, once it undergoes self-thinning, it provides an opportunity for native understory vegetation to recolonize (Francis and Parrotta 2006; Parrotta 2000). Previous studies found that L. leucocephala can promote the seedling establishment and growth of native tree species, thereby potentially improving natural regeneration of tropical dry forests (Santiago Garcia et al. 2008; Wolfe and Van Bloem 2012). Additionally, L. leucocephala is one of the few tree species well adapted to colonize areas occupied by dense tall-grass meadows (e.g., Megathyrsus maximus) (Parrotta 2000).

The objective of our study was to monitor the rate of spread of these three focal species, and the pattern of their co-occurrence, together with other plant species, during post-disturbance colonization of a bulldozer trail. This bulldozer trail was created by the local government in a region of dry forest in the western section of Guánica Forest in Puerto Rico (Jaime 2014). We aimed to determine whether or not colonization by any or all of the focal species was facilitated by bulldozing a path through the forest and, if so, at what probability of spread and abundance. Answering such questions contributes to deeper understanding of how three plant species from two different functional groups may interact during post-disturbance colonization, as well as how they may respond spatially to native plant communities regenerating immediately after such disturbance. In turn, this will provide valuable insight about early plant colonization and its potential to shape the vegetation not only in disturbed areas, but over the long term, in other parts of a fully developed tropical dry forest ecosystem.

\section{Methods}

Study site

The site for this study is located $\sim 13-69 \mathrm{~m}$ above sea level near road PR-325 in the Ensenada sector of Guánica Forest (Fig. 1). Annual rainfall in Ensenada averages $860 \mathrm{~mm} /$ year and is highly seasonal, with six dry months (December-March and June-July) split by two wet periods from April to May and August to November (Murphy and Lugo 1986). The air temperature averages $25.1{ }^{\circ} \mathrm{C}$ with low annual variation. The Guánica Forest, which was designated as an International Biosphere Reserve by the United Nations in 1981, is the best remaining example of tropical dry forest flora in Puerto Rico and the Caribbean islands (720 species, with 18 endemic tree species, few exotic species, and 4 endangered species listed by the US Fish and Wildlife Service) (Monsegur-Rivera 2009). Its status as a biosphere reserve emphasizes its perceived value for biodiversity conservation as well as ecological research (Acevedo-Rodríguez and Strong 2008; Maunder et al. 2008; Francisco-Ortega et al. 2007).

The ecology of seasonally dry tropical forests has been well studied (Molina Colón et al. 2011; Vieira and Scariot 2006; Molina Colón and Lugo 2006; SanchezAzofeifa et al. 2005; Murphy and Lugo 1986, 1995). Their plant community structure can vary widely along a continuum ranging from tall stands of semi-deciduous trees to semi-savannas dominated by plants from the Cactaceae family (Vieira and Scariot 2006; Murphy and Lugo 1995). Most species in the tropical dry forest ecoregion are adapted to tolerate a range of mesic to xeric soil moisture regimes. In terms of phenology and level of deciduousness, $>50 \%$ of trees commonly found in tropical dry forests are drought-deciduous, with peak biomass and reproduction during the rainy season for species with fleshy fruits, while species with winddispersed and gravity-dispersed fruits mature during the dry season. Because of unpredictable rainfall patterns and prolonged dry periods, seed germination can be delayed through dormancy until the next rainy season or sometimes can result in high rates of seedling mortality (Murphy and Lugo 1995).

The Puerto Rico Electric Power Authority created a 570 -m long by $\sim 7.3-\mathrm{m}$ wide (on average) bulldozer trail into the study site as an attempt to control a wildfire resulting from a downed high-voltage power line inside the forest on March 13, 2012 (Fig. 1). The fire burned approximately 10 ha of tropical dry forest. The fire did not burn uniformly across the landscape, so patches of surviving vegetation were distributed throughout the burned area. The bulldozer trail began at the roadside of a paved road (PR-325) and ended $5 \mathrm{~m}$ past the highvoltage power-line tower that triggered the wildfire (Fig. 1). The trail had a 31-m elevation increase from the 


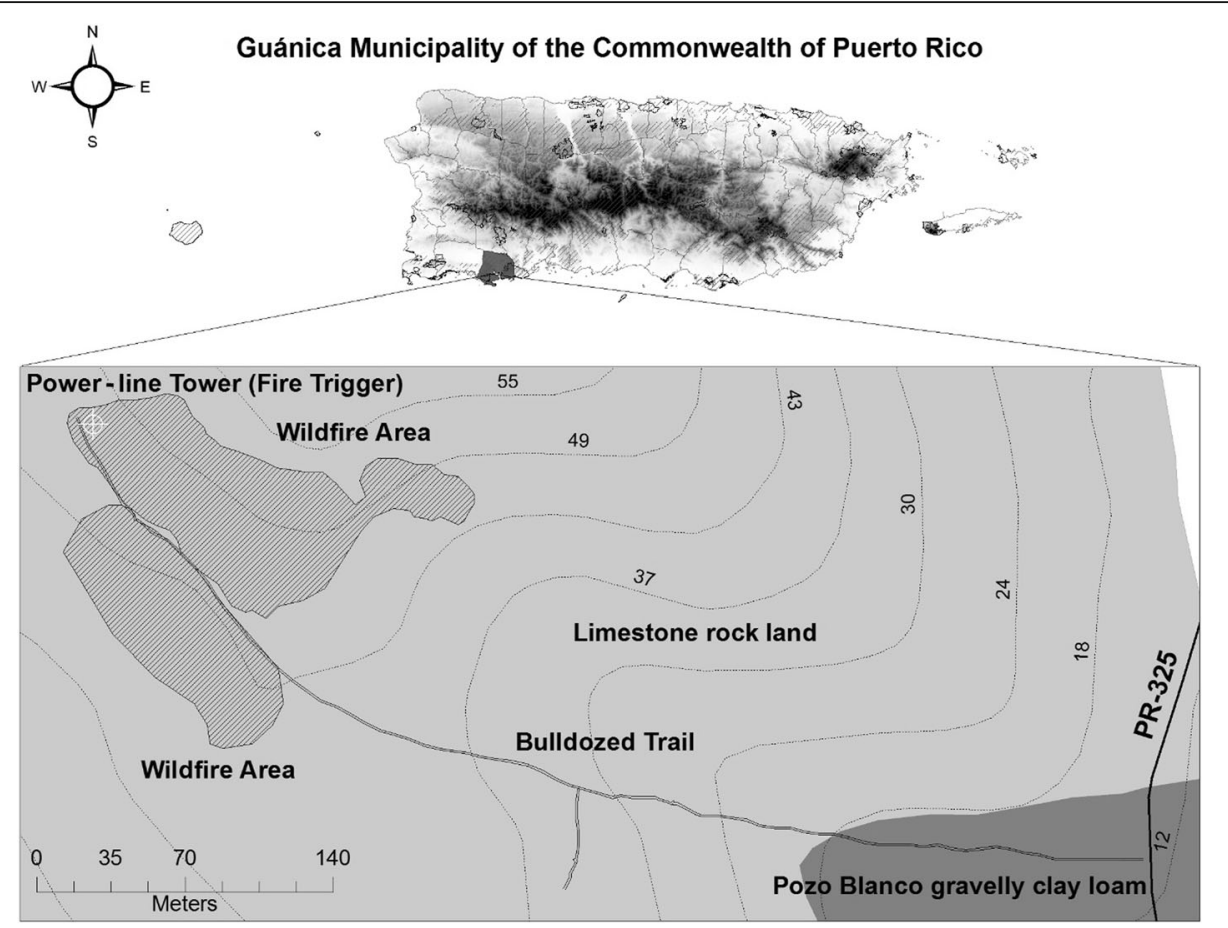

Fig. 1 Map of the 570-m long bulldozer trail from road PR-325 (at right) to the power-line tower that was the fire source (shaded area near top left). Elevation on contours in meters. Fire occurred in mature, native-dominated forest in the Ensenada sector of Guánica Forest, PR. Transect point 0 is at the intersection of the trail and PR 325

roadside to the high-voltage tower area (Fig. 1). The first $401 \mathrm{~m}$ from PR-325 was through mature dry forest. The last $169 \mathrm{~m}$ crossed through mature forest with $U$. virgata in the herbaceous understory that burned when the power line fell. Large, dense colonies of M. maximus dominated areas along the side of the road (PR-325) near where the bulldozer trail started. However, colonies of the invasive $M$. maximus were absent inside the undisturbed forest in March 2012. We are confident that the area did not have M. maximus before the fire and bulldozer disturbances (S. J. Van Bloem, Pers. Obs.), and previous investigations within this field site indicated similar findings (e.g., Pérez Martínez 2007, Wolfe 2008). In addition, we did not observe $M$. maximus in adjacent control plots immediately after the disturbance. Similar to M. maximus, L. leucocephala was well established along PR-325, however, scattered individuals were also located inside the undisturbed forest.

\section{Experimental design and measurement of bulldozed trail cross-transects}

We established 38 cross-transect replicates ( $7 \mathrm{~m} \mathrm{long})$ perpendicular to the bulldozer trail at $15-\mathrm{m}$ intervals, with the first cross-transect set perpendicular to the roadside of PR-325 where it connected to the bulldozer trail (Fig. 1). The 15-m spacing between cross-transects was a practical choice given our available project resources, as it enabled repeated and consistent sampling of the full length of the trial at three different survey times. We identified the species of sprouts or seedlings present at intercept points located every $20 \mathrm{~cm}$ along each cross-transect line. We sampled each cross-transect in July 2012, December 2012, and July 2013. The first sampling period captured initial colonization, while the second and third surveys measured the influence of the wet fall and dry winter periods, respectively, for a full-year cycle of post-disturbance response from the plant community perspective. We recorded the natural regeneration of the plant community (e.g., germination or resprouting from remnant vegetation) as abundance (\%) of vegetation coverage present along each replicated cross-transect. More precisely, we counted the number of points $\left(a_{i j}\right)$ with vegetation in a given cross-transect $(i j)$ divided by the total number of points in the cross-transect $\left(A_{i j}\right)$ : $\left[\left(\sum_{j=1}^{n} a_{i j} / A_{i j}\right) \times 100\right]$ (Fig. 2).

\section{Statistical analysis}

To model the post-disturbance colonization activity of $M$. maximus, L. leucocephala, and $U$. virgata, we developed sets of binary logistic regression models (GLM, family = "binomial") based on the presence or absence of the three focal species, as well as the presence of other plants, along each cross-transect. We adopted the probability of 


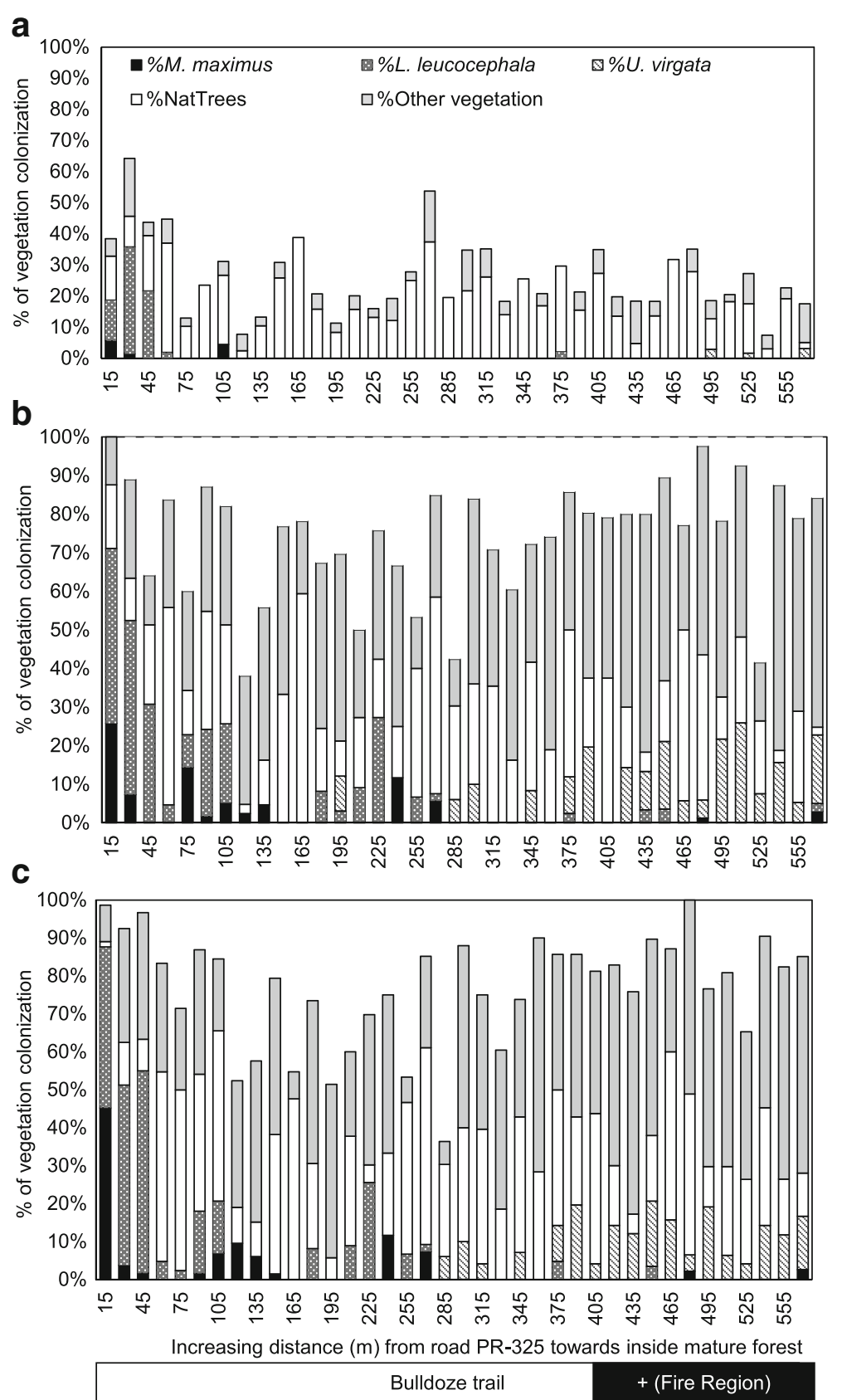

Fig. 2 Post-bulldozing colonization patterns recorded during a July 2012, b December 2012, and c July 2013. Note: Locations where none of the three species under study occurred were dominated by sprouting native trees, other vegetation (i.e., any vegetation other than the focal species or native trees), or barren land (the difference between the bar and 100\%)

occurrence, $\Psi$ (Aho et al. 2014; Cove et al. 2012; MacKenzie et al. 2006; Pan 2001), represented in this case by the predicted probabilities (i.e., of species occurrence at a given distance along the trail) from each GLM model, as an indicator of the expected pattern of post-disturbance colonization. Each dependent variable was tested against a particular independent variable or set of interacting variables that were considered to have a possible impact on species distribution. We used the statistical software RGui 3.1.2 (R Development Core Team 2014) and the corresponding statistical packages MASS, VIF (O'Brien 2007), car, and ggplot2 for this analysis.

We developed ten models to test specific hypotheses for $M$. maximus, $U$. virgata, and $L$. leucocephala. Although we assumed that a species is naturally more likely to colonize near its point of origin and less likely 
away from its source point, we further wanted to test whether other ecological parameters accelerated or decelerated a species' colonization (Table 1). We constructed our first model set (i.e., one model for each focal species) as the null hypotheses $[\psi()$.$] to test the$ premise that the occurrence of each species along the bulldozed trail was neutral, i.e., not following any identifiable trend related to distance, temporal patterns due to elapsed time, the effect of presence of other species (grouped by origin and functional groups), or the combination of all of those parameters. In turn, our second model set [ $\psi$ (Dist_z)] tested the spatial influence that distance from the road had over a species' colonization pattern along the bulldozer trail, thus providing a simple baseline dispersal model for each species. Since there are high densities of $M$. maximus and L. leucocephala along PR-325, we expected the coefficient for this variable to be negative for these two species (probability declines with distance from the road). However, the establishment of $U$. virgata was primarily near the end of the bulldozer trail, so we expected the coefficient to be positive in this case (probability increases with distance from the road). We aimed to reduce the chance of omitting confounding factors; in our third model set [ $\psi$ (Time)], we added an elapsed time covariate to the baseline Dist $z$ to address temporal patterns in colonization over the full year while incorporating each species' source point and possible movement along the bulldozer trail. To evaluate the effect of presence of $U$. virgata and $L$. leucocephala on $M$. maximus colonization, our fourth model [ $\psi($ NatColo $)]$ - i.e., a single model for M. maximus only - added a covariate representing the combined presence of $U$. virgata and $L$. leucocephala to the $[\psi$ (Time)] model. We applied the same approach in a fifth model [ $\psi$ (InvColo)] for U. virgata, combining the effect of the presence of the other two focal species, M. maximus and L. leucocephala, as one covariate. Since $L$. leucocephala is the only focal species from a different functional group and has the potential to restore canopy cover in post-disturbed dry forests, we addressed the possible effect of the presence of both focal grass species on its presence by combining $M$. maximus and $U$. virgata in our sixth model [ $\psi$ (GrassColo)].

As for natural regeneration of the system after the disturbance, we developed a seventh model set $[\psi$ (NatVeg)] representing the effect of the combined

Table 1 Descriptions and expected direction of occurrence probability $(\psi)$ models for Megathyrsus maximus [M], Leucaena leucocephala [L], and Uniola virgata [U] along the 570-m bulldozed trail in the Ensenada sector of the Guánica Forest. All models tested for significance at $a=0.05$

\begin{tabular}{|c|c|c|c|}
\hline Hypothesis & Model & Structure of model & Expected results \\
\hline $\begin{array}{l}\text { 1. [All]: no influence of any factor } \\
\text { over species }\end{array}$ & $\psi()$. & $\beta_{0}$ & - \\
\hline $\begin{array}{l}\text { 2. [M, L]: negative influence of } \\
\text { trail distance from road }\end{array}$ & $\psi$ (Dist_z) & $\beta_{0}+\beta_{1}$ (Dist_z) & $\beta_{1}<0$ \\
\hline $\begin{array}{l}{[\cup] \text { : positive influence of trail }} \\
\text { distance from road }\end{array}$ & $\psi$ (Dist_z) & $\beta_{0}+\beta_{1}$ (Dist_z) & $\beta_{1}>0$ \\
\hline $\begin{array}{l}\text { 3. [All]: positive influence of distance } \\
\text { and temporal patterns }\end{array}$ & $\psi$ (Time) & $\begin{array}{l}\beta_{0}+\beta_{1} \text { (Dist_z) }+\beta_{2} \text { (July 2012) }+\beta_{3} \text { (December 2012) }+\beta_{4} \text { (July } \\
\text { 2013) }\end{array}$ & $\begin{array}{l}\beta_{1}<0, \beta_{2}<0 \\
\beta_{3}>0, \beta_{4}>0\end{array}$ \\
\hline $\begin{array}{l}\text { 4. [M]: negative influence of } U \text {. virgata } \\
\text { and L. leucocephala presence }\end{array}$ & $\psi($ NatColo) & $\begin{array}{l}\beta_{0}+\beta_{1}(\text { Dist_z })+\beta_{2}\left(\text { July 2012) }+\beta_{3} \text { (December 2012) }+\beta_{4}\right. \\
\text { (July 2013) }+\beta_{5} \text { (U. virgata and L. leucocephala) }\end{array}$ & $\begin{array}{l}\beta_{1}<0, \beta_{2}<0 \\
\beta_{3}>0, \beta_{4}<0 \\
\beta_{5}<0\end{array}$ \\
\hline $\begin{array}{l}\text { 5. [U]: negative influence of } M \text {. maximus } \\
\text { and L. leucocephala presence }\end{array}$ & $\psi(\operatorname{lnv}$ Colo) & $\begin{array}{l}\beta_{0}+\beta_{1}\left(\text { Dist_z) }+\beta_{2}\left(\text { July 2012) }+\beta_{3}\left(\text { December 2012) }+\beta_{4}\right.\right.\right. \\
\text { (July 2013) }+\beta_{5}(\text { M. maximus and L. leucocephala })\end{array}$ & $\begin{array}{l}\beta_{1} \leq 0, \beta_{2}<0 \\
\beta_{3}>0, \beta_{4}<0 \\
\beta_{5}<0\end{array}$ \\
\hline $\begin{array}{l}\text { 6. [L]: negative influence of M. maximus } \\
\text { and U. virgata presence }\end{array}$ & $\Psi$ (GrassColo) & $\begin{array}{l}\beta_{0}+\beta_{1}(\text { Dist_z })+\beta_{2} \text { (July 2012) }+\beta_{3}\left(\text { December 2012) }+\beta_{4}\right. \\
\text { (July 2013) }+\beta_{5} \text { (M. maximus and U. virgata) }\end{array}$ & $\begin{array}{l}\beta_{1} \leq 0, \beta_{2}<0 \\
\beta_{3}>0, \beta_{4}<0 \\
\beta_{5}>0\end{array}$ \\
\hline $\begin{array}{l}\text { 7. [All]: negative influence of the } \\
\text { presence of native trees and } \\
\text { other vegetation }\end{array}$ & $\psi($ NatVeg) & $\begin{array}{l}\beta_{0}+\beta_{1}(\text { Dist_z })+\beta_{2}\left(\text { July 2012) }+\beta_{3}\left(\text { December 2012) }+\beta_{4}\right.\right. \\
\text { (July 2013) }+\beta_{5} \text { (other vegetation) }\end{array}$ & $\begin{array}{l}\beta_{1} \leq 0, \beta_{2}<0 \\
\beta_{3}>0, \beta_{4}<0 \\
\beta_{5}<0\end{array}$ \\
\hline $\begin{array}{l}\text { 8. [M]: negative influence of all } \\
\text { effects on } M \text {. maximus presence }\end{array}$ & $\Psi$ (AllColoNat) & $\begin{array}{l}\beta_{0}+\beta_{1} \text { (Dist_z) }+\beta_{2} \text { (July 2012) }+\beta_{3} \text { (December 2012) }+\beta_{4} \text { (July } \\
2013)+\beta_{5} \text { (U. virgata and L. leucocephala) }+\beta_{6} \text { (other vegetation) }\end{array}$ & $\begin{array}{l}\beta_{1} \leq 0, \beta_{2}<0 \\
\beta_{3}>0, \beta_{4}<0 \\
\beta_{5}<0, \beta_{6}<0\end{array}$ \\
\hline $\begin{array}{l}\text { 9. [U]: negative influence of all } \\
\text { effects on U. virgata presence }\end{array}$ & $\psi($ AllCololnv) & $\begin{array}{l}\left.\beta_{0}+\beta_{1} \text { (Dist_z }\right)+\beta_{2} \text { (July 2012) }+\beta_{3} \text { (December 2012) }+\beta_{4} \text { (July } \\
2013)+\beta_{5}(\text { M. maximus and L. leucocephala })+\beta_{6} \text { (other vegetation) }\end{array}$ & $\begin{array}{l}\beta_{1} \leq 0, \beta_{2}<0 \\
\beta_{3}>0, \beta_{4}<0 \\
\beta_{5}<0, \beta_{6}<0\end{array}$ \\
\hline $\begin{array}{l}\text { 10. [L]: negative influence of all } \\
\text { effects on } L \text {. leucocephala } \\
\text { presence }\end{array}$ & $\psi$ (AllColoGrass) & $\begin{array}{l}\beta_{0}+\beta_{1} \text { (Dist_z) }+\beta_{2} \text { (July 2012) }+\beta_{3} \text { (December 2012) }+\beta_{4} \\
\text { (July 2013) }+\beta_{5} \text { (M. maximus and U. virgata) }+\beta_{6} \text { (other vegetation) }\end{array}$ & $\begin{array}{l}\beta_{1} \leq 0, \beta_{2}<0 \\
\beta_{3}>0, \beta_{4}<0 \\
\beta_{5}<0, \beta_{6}<0\end{array}$ \\
\hline
\end{tabular}


presence of recolonizing native trees and other plants (i.e., native and introduced species; see Table 2) in the disturbed area on the presence of each of the three focal species. Since it is plausible that all of the aforementioned effects of presence, distance, and temporal variations could place collective pressure on each focal species' colonization, we developed three all-inclusive models $[\psi$ (AllColoNat), $\psi$ (AllColoInv), and $\psi$ (AllColoGrass)] by adding a factorial variable representing other vegetation (all functional groups) to the previous models $4-6$.

\section{Results}

Over the course of the year, colonization of the bulldozer trail by each of the three focal species depended on to their distance from the road. For M. maximus and L. leucocephala, colonization was higher near the road and subsequently decreased in occurrence $(\psi)$ as the distance from the roadside increased (Fig. 2a, b). By July 2013 (i.e., the last of the three survey periods), these two species were found fairly regularly up to $270 \mathrm{~m}$ from PR325 along the trail and in isolated patches beyond that (Fig. 2c). Uniola virgata reestablished itself from the far end of the bulldozed trail (i.e., inside the forest) and moved toward PR-325 over time (Fig. 2c). After 1 year, $U$. virgata successfully recolonized the area that had burned from the wildfire and subsequently spread an additional $115 \mathrm{~m}$ along the bulldozer trail. It was also observed co-occurring in some cross-transects colonized by M. maximus and L. leucocephala. Regardless of M. maximus and L. leucocephala colonization, native trees and plants from other functional groups (i.e., species other than $U$. virgata) effectively repopulated the midsection of the bulldozer trail, creating dense natural regeneration by the first survey in July 2012 (Fig. 2a).

\section{Effects of temporal pattern and impact of co-occurrence between functional groups}

For each of our focal species, colonization along the trail was affected by temporal pattern. As would be expected, greater elapsed time resulted in further dispersal from source populations. However, those effects were not consistent between sampling events. Dispersal by July 2012 for each species was mainly limited to areas very near well-established source populations (small $\beta_{2}$ values in Table 3). The December 2012 sample, which included the fall rainy period, showed more rapid colonization (high $\beta_{3}$ values) followed by little change during the primarily dry period between December 2012 and July 2013 (similar $\beta_{3}$ and $\beta_{4}$ values; Table 3). Analysis of occupancy in December 2012 showed that M. maximus and $L$. leucocephala were more effective dispersers than $U$. virgata and their dispersal continued over longer distances, as evidenced by shallower slopes of the occurrence curve (Fig. 3a, b). At that time, there was a $50 \%$ chance that $M$. maximus would have dispersed to a distance of $160 \mathrm{~m}(95 \% \mathrm{CI}[0 \mathrm{~m}, 265 \mathrm{~m}])$ and L. leucocephala $270 \mathrm{~m}(95 \% \mathrm{CI}[0 \mathrm{~m}, 397 \mathrm{~m}])$ from the road. Uniola virgata had a steeper slope that reflected lower dispersal ability, particularly when considering that much of its dispersal could have come from unburned patches near the trail, while the primary seed source for both $M$. maximus and $L$ leucocephala was the roadside vegetation of PR-325 near the start of the bulldozer trail.

Colonization by native trees and other vegetation (Table 2) had no significant effect on colonization by $L$. leucocephala or $U$. virgata, but did have a significant effect on $M$. maximus colonization ( $\beta$ values for NatVeg and AllColoNat, Table 3). In both December 2012 and July 2013, there was an observable spatial pattern (Fig. 2) wherein $M$. maximus was either absent or rare in crosstransects that were dominated by native trees and other vegetation. This was most pronounced in the portion of the bulldozer trail farthest away from PR-325.

\section{Discussion}

In 1 year, M. maximus and L. leucocephala colonized, with fairly high abundance, throughout the first $270 \mathrm{~m}$ of the bulldozer trail from the roadside into the forest (Fig. 2). The two species showed a 0.5 probability of reaching as far as 160 and $270 \mathrm{~m}$ into the forest, respectively, according to our post-bulldozing (Time) model (Fig. 3a, b), and both increased in coverage during December 2012 and July 2013 (Fig. 2b, c). The probability of occurrence for M. maximus and L. leucocephala at a given location along the bulldozer trail declined from about 0.65 and 0.80 , respectively, at the starting point of the trail near PR-325 to probabilities of less than 0.2 and 0.3 , respectively, at $400 \mathrm{~m}$ into the forest (Fig. 3a, b). Although M. maximus was observed at the end of the bulldozer trail (i.e., at $570 \mathrm{~m}$ from PR-325), we cannot say definitively that it reached that distance solely from the roadside populations. However, since no M. maximus individuals were observed elsewhere in the forest, we believe this is a reasonable supposition, especially since $M$. maximus and other invasive grasses have been shown to spread successfully along roadways and dominate roadside flora due to the constant movement of motor vehicles serving as dispersal agents (Von der Lippe and Kowarik 2007; Veldman and Putz 2010; Freitas et al. 2010). In contrast, and unlike $M$. maximus, there were isolated individuals of $L$. leucocephala distributed through the study site before the wildfire, so L. leucocephala colonizers seen near the end of the trail could have originated from a variety of locations other than the roadside vegetation.

We acknowledge the possibility that a seedbed containing M. maximus or L. leucocephala, or both, was 
Table 2 Plant species and species origin grouped by growth habit recorded in vegetation surveys of the 38 transverse transects along the 570-m-long bulldozer trail from July 2012 to July 2013 in the Ensenada sector of Guánica Forest, Puerto Rico

\begin{tabular}{|c|c|c|}
\hline Species (family) $n=55$ species & Native & Introduced \\
\hline \multicolumn{3}{|l|}{ Grasses } \\
\hline Bothriochloa pertusa (Poaceae) & & $x$ \\
\hline Bouteloua americana (Poaceae) & $x$ & \\
\hline Bouteloua dactyloides (Poaceae) & & $x$ \\
\hline Megathyrsus maximus (Poaceae) & & $x$ \\
\hline Melinis repens (Poaceae) & & $x$ \\
\hline Pennisetum ciliare (Poaceae) & & $x$ \\
\hline Uniola virgata ${ }^{a}$ (Poaceae) & $x$ & \\
\hline \multicolumn{3}{|l|}{ Herbaceous, vines, and forbs } \\
\hline Cuscuta umbellata (Cuscutaceae) & $x$ & \\
\hline Ipomoea alba (Convolvulaceae) & $x$ & \\
\hline Ipomoea carnea (Convolvulacea) & & $x$ \\
\hline Jacquemontia cumanensis (Convolvulaceae) & $x$ & \\
\hline Malvastrum americanum (Malvaceae) & $x$ & \\
\hline Melochia tomentosa (Sterculiaceae) & $x$ & \\
\hline Mimosa ceratonia (Fabaceae) & $x$ & \\
\hline Mimosa pudica (Fabaceae) & $x$ & \\
\hline Scleria pauciflora (Cyperaceae) & & $x$ \\
\hline Sida acuta (Malvaceae) & $x$ & \\
\hline Stigmaphyllon emarginatum (Malpighiaceae) & $x$ & \\
\hline Waltheria indica (Sterculiaceae) & $x$ & \\
\hline Wedelia calycina (Asteraceae) & $x$ & \\
\hline \multicolumn{3}{|l|}{ Trees and shrubs } \\
\hline Bourreria succulenta (Boraginaceae) & $x$ & \\
\hline Bucida buceras (Combretaceae) & $x$ & \\
\hline Bursera simaruba (Burseraceae) & $x$ & \\
\hline Coccoloba diversifolia (Polygonaceae) & $x$ & \\
\hline Coccoloba microstachya (Polygonaceae) & $x$ & \\
\hline Colubrina arborescens (Rhamnaceae) & $x$ & \\
\hline Colubrina glandulosa (Rhamnaceae) & $x$ & \\
\hline Comocladia dodonaea (Anacardiaceae) & $x$ & \\
\hline Corchorus hirsutus (Tiliaceae) & $x$ & \\
\hline Crossopetalum rhacoma (Celastraceae) & $x$ & \\
\hline Croton discolor (Euphorbiaceae) & $x$ & \\
\hline Croton flavens (Euphorbiaceae) & $x$ & \\
\hline Croton impressus (Euphorbiaceae) & $x$ & \\
\hline Croton lucidus (Euphorbiaceae) & $x$ & \\
\hline Colubrina elliptica (Rhamnaceae) & $x$ & \\
\hline Erythroxylum rotundifolium (Erythroxylaceae) & $x$ & \\
\hline Eugenia foetida (Myrtaceae) & $x$ & \\
\hline Eugenia ligustrina (Myrtaceae) & $x$ & \\
\hline Eugenia rhombea (Myrtaceae) & $x$ & \\
\hline
\end{tabular}


Table 2 Plant species and species origin grouped by growth habit recorded in vegetation surveys of the 38 transverse transects along the 570-m-long bulldozer trail from July 2012 to July 2013 in the Ensenada sector of Guánica Forest, Puerto Rico (Continued)

\begin{tabular}{|c|c|c|}
\hline Species (family) $n=55$ species & Native & Introduced \\
\hline Exostema caribaeum (Rubiaceae) & $x$ & \\
\hline Guaiacum sanctum (Zygophyllaceae) & $x$ & \\
\hline Guettarda scabra (Rubiaceae) & $x$ & \\
\hline Guettarda krugii (Rubiaceae) & $x$ & \\
\hline Gymnanthes lucida (Euphorbiaceae) & $x$ & \\
\hline Helicteres jamaicensis (Sterculiaceae) & $x$ & \\
\hline Krameria ixine (Krameriaceae) & $x$ & \\
\hline Leucaena leucocephala (Fabaceae) & & $x$ \\
\hline Lantana camara (Verbenaceae) & & $x$ \\
\hline Petitia domingensis (Verbenaceae) & $x$ & \\
\hline Pictetia aculeata (Fabaceae) & $x$ & \\
\hline Pithecellobium unguis-cati (Fabaceae) & $x$ & \\
\hline Prosopis juliflora (Fabaceae) & & $x$ \\
\hline Pisonia albida (Nyctaginaceae) & & $x$ \\
\hline Randia aculeata (Rubiaceae) & $x$ & \\
\hline Randia portoricensis (Rubiaceae) & $x$ & \\
\hline Sideroxylon portoricense (Sapotaceae) & $x$ & \\
\hline
\end{tabular}

"Plant Database." Welcome to the PLANTS Database | USDA PLANTS. NRCS, Last Modified: 12 June 2017. Web. 16 June 2017

${ }^{a}$ Focal species addressed in this study

already present before the bulldozer disturbance took place. Thus, establishment of these species could have occurred from this existing seedbed. Even if-as we believe happened-the seedbed was scraped away by the bulldozer, after the bulldozing, the vehicles used to control the wildfire and repair the power lines and poles inside the forest could have dispersed seed into the newly disturbed habitats where M. maximus and L. leucocephala seeds were not present previously.

Regardless, our results suggest that, for both $M$. maximus and L. leucocephala, the two most crucial factors in the prediction of invasion are the distance from the likeliest seed source (i.e., highly invaded roadside areas) and the rate of spread observed through time. With respect to both species, the probability of occurrence $(\psi)$ models fitted to the observed colonization patterns (Table 3) emphasized the importance of time since disturbance as a predictor. Furthermore, results from the $\psi$ (Time) and $\psi$ (AllColoNat) models suggested that regeneration of other, primarily woody, species (i.e., other than L. leucocephala) across a substantial portion of the bulldozer trail served as a biotic constraint on the presence of $M$. maximus (Table 3). Such a pattern has also been observed in previous studies in this tropical dry forest (Molina Colón and Lugo 2006; Van Bloem et al. 2005). Although we did not develop models based on regeneration by each of these other plant species, we constructed model parameters that accounted for all of them collectively (Table 1). We also observed that most of the regeneration of these other species happened from the root, basal, or stump sprouts and developed rapidly after the disturbance (Fig. 3a) as a result of resource allocation and acquisition by roots. Sprouting is a typical post-disturbance response in tropical dry forests (Van Bloem et al. 2007). Moreover, when conditions are appropriate, resprouting is an active physiological response that favors native woody vegetation, allowing them to out-compete grasses by shading them out.

Uniola virgata colonized from the end of the trail, where the fire started, to near the midsection of the bulldozer trail. Since this native species was already established in patches throughout the forest and alongside the trail, $U$. virgata had the opportunity to colonize or sprout from multiple locations along the disturbed area and build new colonies quickly. In just 13 months, $U$. virgata regenerated rapidly from some residual stolons that survived the fire or from seed dispersal inside the bulldozer trail. This dispersal pattern was similar to $M$. maximus in that both grasses established in areas closer to external propagule sources first. $U$. virgata declined in presence abruptly near the midsection of the bulldozer trail, which was instead dominated by woody sprouts. This resulting pattern could represent a preliminary indicator of potential competition between $U$. virgata (or perhaps other native grasses) and woody vegetation that could ultimately limit the ability of the grass to disperse in the long run, but investigating such 
Table 3 Significant model parameter results for M. maximus, L. leucocephala, and U. virgata probability of occurrence ( $\Psi)$ derived from cross-transect surveys conducted along the 570-m bulldozed trail in the Ensenada section of Guánica Forest

\begin{tabular}{|c|c|c|c|c|}
\hline Models & $\beta_{x}$ parameter & Megathyrsus maximus & Leucaena leucocephala & Uniola virgata \\
\hline$\psi$ (Dist_z) & $\beta_{1}$ (Dist_z) & $-1.09 \pm 0.28^{* * *}$ & $-1.12 \pm 0.26^{* * *}$ & $2.21 \pm 0.41^{* * *}$ \\
\hline \multirow[t]{4}{*}{$\psi($ Time) } & $\beta_{1}$ (Dist_z) & $-1.18 \pm 0.30^{* * *}$ & $-1.28 \pm 0.29 * * *$ & $4.12 \pm 0.93^{* * *}$ \\
\hline & $\beta_{2}(\mathrm{Jul}-2012)$ & $-2.63 \pm 0.60^{* * *}$ & $-2.42 \pm 0.56^{* * *}$ & $-6.32 \pm 1.41^{* * *}$ \\
\hline & $\beta_{3}($ Dec-2012) & $1.62 \pm 0.69^{*}$ & $2.13 \pm 0.67^{* *}$ & $5.58 \pm 1.41^{* * *}$ \\
\hline & $\beta_{4}(\mathrm{Jul}-2013)$ & $1.77 \pm 0.69^{*}$ & $1.83 \pm 0.66^{* *}$ & $5.95 \pm 1.48^{* * *}$ \\
\hline \multirow[t]{5}{*}{$\Psi$ (NatVeg) } & $\beta_{1}$ (Dist_z) & $-1.33 \pm 0.33^{* * *}$ & $-1.39 \pm 0.31^{* * *}$ & $4.11 \pm 0.92^{* * *}$ \\
\hline & $\beta_{2}(\mathrm{Jul}-2012)$ & $0.59 \pm 1.61$ & $0.15 \pm 1.57$ & $-5.20 \pm 14.98$ \\
\hline & $\beta_{3}($ Dec-2012) & $1.53 \pm 0.71^{*}$ & $2.07 \pm 0.68^{* *}$ & $5.58 \pm 1.42^{* * *}$ \\
\hline & $\beta_{4}(\mathrm{Jul}-2013)$ & $1.81 \pm 0.71^{*}$ & $1.87 \pm 0.68^{* *}$ & $5.95 \pm 1.48^{* * *}$ \\
\hline & $\beta_{5}$ (natural regeneration) & $-3.33 \pm 1.59^{*}$ & $-2.66 \pm 1.54$ & $-1.12 \pm 14.92$ \\
\hline \multirow[t]{5}{*}{$\Psi$ (NatColo) } & $\beta_{1}$ (Dist_z) & $-1.18 \pm 0.30^{* * *}$ & N/A & N/A \\
\hline & $\beta_{2}(\mathrm{Jul}-2012)$ & $-2.58 \pm 0.61^{* * *}$ & N/A & N/A \\
\hline & $\beta_{3}($ Dec-2012) & $1.69 \pm 0.73^{*}$ & N/A & N/A \\
\hline & $\beta_{4}(\mathrm{Jul}-2013)$ & $1.85 \pm 0.73^{*}$ & N/A & N/A \\
\hline & $\beta_{5}$ (Uniola and Leucaena) & $-0.17 \pm 0.55$ & N/A & N/A \\
\hline \multirow[t]{5}{*}{$\Psi$ (GrassColo) } & $\beta_{1}$ (Dist_z) & N/A & $-1.28 \pm 0.29^{* * *}$ & N/A \\
\hline & $\beta_{2}(\mathrm{Jul}-2012)$ & N/A & $-2.42 \pm 0.58^{* * *}$ & $\mathrm{~N} / \mathrm{A}$ \\
\hline & $\beta_{3}(\mathrm{Dec}-2012)$ & N/A & $2.12 \pm 0.70^{* *}$ & N/A \\
\hline & $\beta_{4}(\mathrm{Jul}-2013)$ & N/A & $1.83 \pm 0.69^{* *}$ & N/A \\
\hline & $\beta_{5}$ (Megathyrsus and Uniola) & $\mathrm{N} / \mathrm{A}$ & $0.01 \pm 0.52$ & $\mathrm{~N} / \mathrm{A}$ \\
\hline \multirow[t]{5}{*}{$\Psi$ (InvColo) } & $\beta_{1}$ (Dist_z) & N/A & N/A & $4.20 \pm 1.04^{* * *}$ \\
\hline & $\beta_{2}(\mathrm{Jul}-2012)$ & N/A & N/A & $-6.44 \pm 1.56^{* * *}$ \\
\hline & $\beta_{3}(\mathrm{Dec}-2012)$ & N/A & N/A & $5.60 \pm 1.44^{* * *}$ \\
\hline & $\beta_{4}(\mathrm{Jul}-2013)$ & N/A & N/A & $5.97 \pm 1.50^{* * *}$ \\
\hline & $\beta_{5}$ (Megathyrsus and Leucaena) & $\mathrm{N} / \mathrm{A}$ & N/A & $0.19 \pm 0.96$ \\
\hline \multirow[t]{6}{*}{$\Psi$ (AllColoNat) } & $\beta_{1}$ (Dist_z) & $-1.34 \pm 0.33^{* * *}$ & N/A & N/A \\
\hline & $\beta_{2}(\mathrm{Jul}-2012)$ & $0.77 \pm 1.65$ & N/A & N/A \\
\hline & $\beta_{3}(\mathrm{Dec}-2012)$ & $1.65 \pm 0.74^{*}$ & N/A & N/A \\
\hline & $\beta_{4}(\mathrm{Jul}-2013)$ & $1.93 \pm 0.75^{* *}$ & N/A & N/A \\
\hline & $\beta_{5}$ (Uniola and Leucaena) & $-0.29 \pm 0.56$ & N/A & N/A \\
\hline & $\beta_{6}$ (native vegetation) & $-3.43 \pm 1.62^{*}$ & N/A & N/A \\
\hline \multirow[t]{6}{*}{$\Psi$ (AllColoGrass) } & $\beta_{1}$ (Dist_z) & N/A & $-1.39 \pm 0.31^{* * *}$ & N/A \\
\hline & $\beta_{2}(\mathrm{Jul}-2012)$ & N/A & $0.19 \pm 1.59$ & N/A \\
\hline & $\beta_{3}(\operatorname{Dec}-2012)$ & $\mathrm{N} / \mathrm{A}$ & $2.09 \pm 0.70^{* *}$ & $\mathrm{~N} / \mathrm{A}$ \\
\hline & $\beta_{4}(\mathrm{Jul}-2013)$ & N/A & $1.89 \pm 0.71^{* *}$ & N/A \\
\hline & $\beta_{5}$ (Megathyrsus and Uniola) & $\mathrm{N} / \mathrm{A}$ & $-0.06 \pm 0.53$ & $\mathrm{~N} / \mathrm{A}$ \\
\hline & $\beta_{6}$ (native vegetation) & N/A & $-2.67 \pm 1.55$ & N/A \\
\hline \multirow[t]{6}{*}{$\Psi$ (AllCololnv) } & $\beta_{1}$ (Dist_z) & N/A & N/A & $4.20 \pm 1.04^{* * *}$ \\
\hline & $\beta_{2}($ Jul-2012) & $\mathrm{N} / \mathrm{A}$ & N/A & $-5.34 \pm 15.55$ \\
\hline & $\beta_{3}(\mathrm{Dec}-2012)$ & N/A & $\mathrm{N} / \mathrm{A}$ & $5.60 \pm 1.44^{* * *}$ \\
\hline & $\beta_{4}(\mathrm{Jul}-2013)$ & N/A & $\mathrm{N} / \mathrm{A}$ & $5.97 \pm 1.50^{* * *}$ \\
\hline & $\beta_{5}$ (Megathyrsus and Leucaena) & N/A & N/A & $0.19 \pm 0.96$ \\
\hline & $\beta_{6}$ (native vegetation) & N/A & N/A & $-1.10 \pm 15.48$ \\
\hline
\end{tabular}



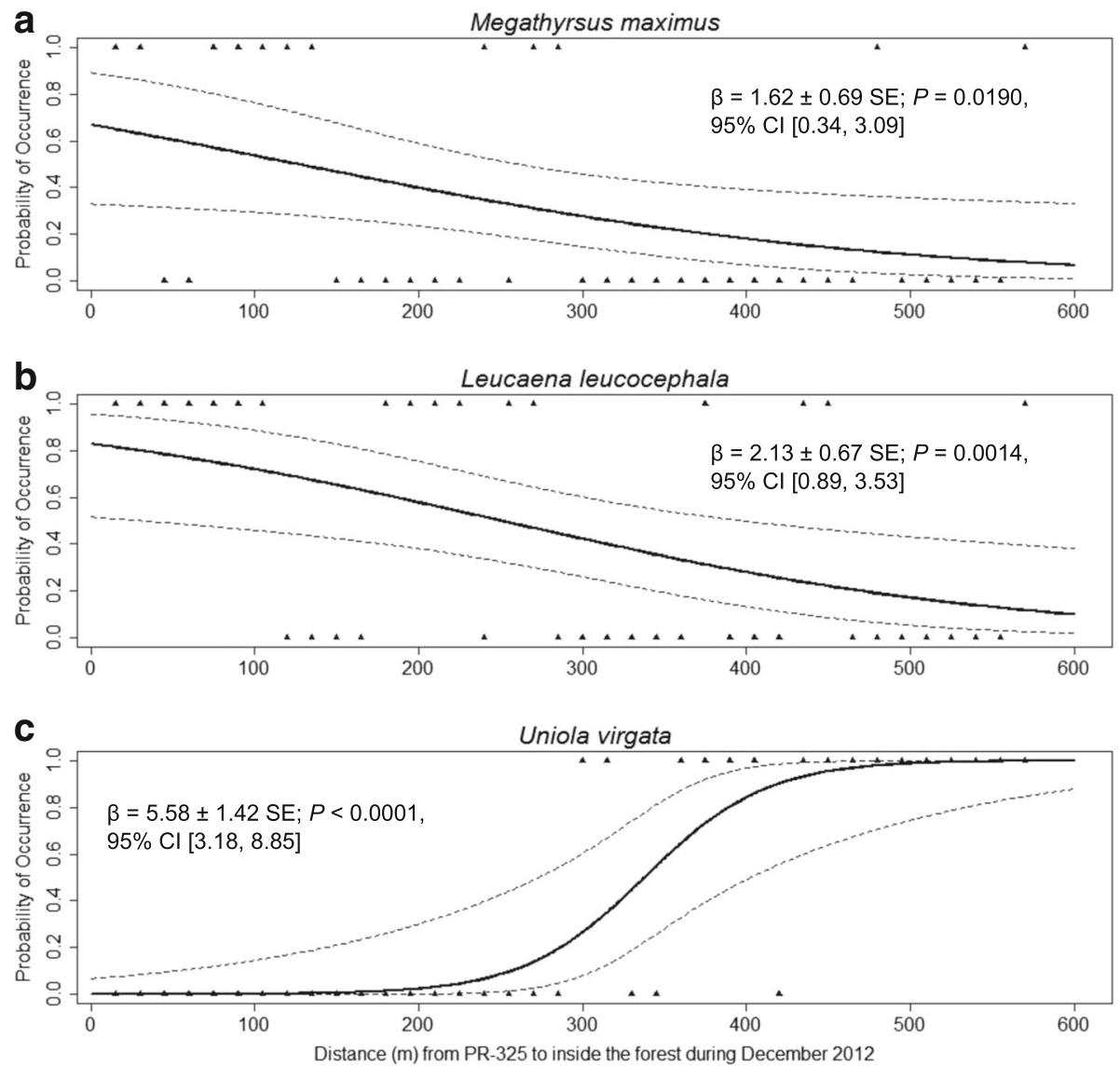

Fig. 3 The probability of occurrence $(\psi)$ for a Megathyrsus maximus, b Leucaena leucocephala, and c Uniola virgata, based on the seasonal model $[\psi$ Time] from the roadside $(0 \mathrm{~m})$ to the power-line region inside the forest $(600 \mathrm{~m})$ for the December 2012 survey

a premise is beyond the scope of this study. Furthermore, conclusive results about the effects of competition in this context, or in the case of M. maximus, would only be possible with exclusion experiments.

Nevertheless, it is clear that once a major disturbance occurs in a tropical forest system, the landscape is vulnerable to invasion by highly competitive non-native grasses (Veldman and Putz 2011; Thaxton et al. 2012a, 2012b). Invasion by opportunistic native grasses can yield similar impacts on forest regeneration (D'Antonio and Meyerson 2002; Cabin et al. 2002; César et al. 2014) but we should reiterate that $U$. virgata was already established within the forest prior to the fire, so it may not have the same effect on regeneration as $M$. maximus. Our study suggests two potential mechanisms by which tropical dry forest ecosystems may resist grass invasion after bulldozing. First, tropical dry forests are well known for stressful abiotic conditions (i.e., they are vulnerable to loss of soil nutrients due to runoff or erosion and have low moisture availability due to high ET and elevated temperatures). These factors are known to favor well-adapted native vegetation (Grime 1979; Murphy and Lugo 1986; Van Bloem et al. 2003; Molina Colón and Lugo 2006). Our results showed that root sprouts and basal shoots from native trees and other, mostly native, woody species (i.e., other than L. leucocephala) dominated early regeneration in the bulldozer trail, particularly at a farther distance from the roadside and within areas with $<10 \%$ of focal species coverage. Unfortunately, native dry forest tree species can struggle to recolonize open areas dominated by grasses, since they tend to grow slowly and are not fire-tolerant (Ramjohn et al. 2012; Wolfe et al. 2014; Wolfe and Van Bloem 2012). However, our study was consistent with previous research suggesting a second potential mechanism. In short, L. leucocephala individuals can establish themselves relatively quickly in disturbed sites shared by invasive grasses such as $M$. maximus and after burns (Parrotta 2000; Santiago Garcia et al. 2008; Ramjohn et al. 2012; Wolfe and Van Bloem 2012). If L. leucocephala colonizes the niche before grasses do, then native tree seedlings will have a better chance of reestablishing. Such successional facilitation is due in part to the ability of L. leucocephala to grow fast-out-competing grasses-and eventually 
create enough shade to restrain grass establishment and rebuilding soil $\mathrm{N}$ content lost from the relocation of topsoil during bulldozing, erosion, or burning (Erickson et al. 2002; Santiago Garcia et al. 2008). Thus, when faced with the possibility of a stable grassland state, managers may consider the nurse-tree effects of $L$. leucocephala and other non-native tree species as a potential pathway for native woody species regeneration.

\section{Conclusions}

Our results demonstrated that bulldozer trails provide highly favorable routes for invasive species to colonize a tropical dry forest (Davis et al. 2005). After only 9 months, the widely introduced $M$. maximus had a $50 \%$ chance of entering $160 \mathrm{~m}$ into the forest and L. leucocephala $270 \mathrm{~m}$ along a newly created bulldozer trail, most likely from a roadside seed source. These findings provide a valuable baseline for understanding the degree to which a one-time disturbance can facilitate invasion into a dry forest. From a management standpoint, when new trails are clearing into intact, native-dominated forest, they should be carefully monitored for the spread of invasive species, and controlling their seed sources may be helpful in minimizing invasion. Species such as M. maximus that can provide good fuel for wildfire (Thaxton et al. 2012a, 2012b) can pose additional threats to mature and secondary dry forests that are not fire-adapted (D'Antonio and Vitousek 1992; Hoffmann et al. 2003; Brooks et al. 2004; Folke et al. 2004). In that regard, if a similar bulldozer disturbance occurs in the future, it may provide an opportunity to replicate the study through a long-term window of observation to better address seasonal pressures and other complex ecological processes in the ecosystem. Still, the sudden plant community responses observed in this study serve for future reference for management strategies directed at conservation efforts in protected tropical dry forests.

\section{Abbreviations}

\begin{tabular}{|c|c|c|}
\hline Terms & Abbreviations & Definition \\
\hline $\begin{array}{l}\text { 1. [All]: no influence of } \\
\text { any factor over species }\end{array}$ & $\psi()$. & $\begin{array}{l}\text { Null hypothesis } \\
\text { [for all species models] }\end{array}$ \\
\hline $\begin{array}{l}\text { 2. [M, L]: negative } \\
\text { influence of trail distance } \\
\text { from road }\end{array}$ & $\psi$ (Dist_z) & $\begin{array}{l}\text { Distance (meters) } \\
\text { [for M. maximus and } \\
\text { L. leucocephala models] }\end{array}$ \\
\hline $\begin{array}{l}{[U] \text { : positive influence of }} \\
\text { trail distance from road }\end{array}$ & $\psi$ (Dist_z) & $\begin{array}{l}\text { Distance (meters) } \\
\text { [for U. virgata model] }\end{array}$ \\
\hline $\begin{array}{l}\text { 3. [All]: positive influence } \\
\text { of distance and } \\
\text { temporal patterns }\end{array}$ & $\psi$ (Time) & $\begin{array}{l}\text { Distance (meters) }+ \\
\text { temporal patterns } \\
\text { [for all species models] }\end{array}$ \\
\hline $\begin{array}{l}\text { 4. [M]: negative influence } \\
\text { of U. virgata and } L \text {. } \\
\text { leucocephala presence }\end{array}$ & $\psi($ NatColo) & $\begin{array}{l}\text { Distance (meters) }+ \\
\text { temporal } \\
\text { patterns }+ \text { colonization } \\
\text { of U. virgata and } L \text {. }\end{array}$ \\
\hline
\end{tabular}

(Continued)

\begin{tabular}{|c|c|c|}
\hline & & $\begin{array}{l}\text { leucocephala [for } M \text {. } \\
\text { maximus model] }\end{array}$ \\
\hline $\begin{array}{l}\text { 5. [U]: negative influence } \\
\text { of } M \text {. maximus and } L \text {. } \\
\text { leucocephala presence }\end{array}$ & $\psi($ InvColo) & $\begin{array}{l}\text { Distance } \\
\text { (meters) + temporal } \\
\text { patterns + colonization } \\
\text { from } M \text {. maximus and } L \text {. } \\
\text { leucocephala [for } U \text {. } \\
\text { virgata model] }\end{array}$ \\
\hline $\begin{array}{l}\text { 6. [L]: negative influence } \\
\text { of } M \text {. maximus and } U \text {. } \\
\text { virgata presence }\end{array}$ & $\Psi$ (GrassColo) & $\begin{array}{l}\text { Distance } \\
\text { (meters) + temporal } \\
\text { patterns + colonization of } \\
\text { M. maximus and U. virgata } \\
\text { [for L. leucocephala model] }\end{array}$ \\
\hline $\begin{array}{l}\text { 7. [All]: negative influence } \\
\text { of the presence of native } \\
\text { trees and other vegetation }\end{array}$ & $\Psi$ (NatVeg) & $\begin{array}{l}\text { Distance } \\
\text { (meters) + temporal } \\
\text { patterns + colonization } \\
\text { of other vegetation } \\
\text { [for all species models] }\end{array}$ \\
\hline $\begin{array}{l}\text { 8. [M]: negative influence } \\
\text { of all effects on } M \text {. } \\
\text { maximus presence }\end{array}$ & $\begin{array}{l}\Psi \\
\text { (AllColoNat) }\end{array}$ & $\begin{array}{l}\text { Distance } \\
\text { (meters) + temporal } \\
\text { patterns + colonization } \\
\text { from U. virgata, L. } \\
\text { leucocephala + other } \\
\text { vegetation } \\
\text { [for } M . \text { maximus model] }\end{array}$ \\
\hline $\begin{array}{l}\text { 9. [U]: negative influence } \\
\text { of all effects on U. virgata } \\
\text { presence }\end{array}$ & $\begin{array}{l}\Psi \\
\text { (AllCololnv) }\end{array}$ & $\begin{array}{l}\text { Distance } \\
\text { (meters) + temporal } \\
\text { patterns + colonization } \\
\text { from M. maximus, L. } \\
\text { leucocephala + other } \\
\text { vegetation [for U. virgata } \\
\text { model] }\end{array}$ \\
\hline $\begin{array}{l}\text { 10. [L]: negative } \\
\text { influence of all effects } \\
\text { on L. leucocephala } \\
\text { presence }\end{array}$ & $\begin{array}{l}\Psi \\
\text { (AllColoGrass) }\end{array}$ & $\begin{array}{l}\text { Distance } \\
\text { (meters) + temporal } \\
\text { patterns } \\
\text { (time) + colonization from } \\
M . \text { maximus and } U \text {. } \\
\text { virgata + other vegetation } \\
\text { [for } L \text {. leucocephala model] }\end{array}$ \\
\hline
\end{tabular}

\section{Acknowledgements}

We thank J. M. Thaxton for helping with the development of the sampling methods and conceptualization of this project. We also thank the biologist Miguel Canals Mora (Guánica Forest Manager) for facilitating access to the forest site. Special thanks to Ariel Lugo, T. A. P. Allerton, A. J. Acevedo Morales, J. Rodriguez-Irizary, E. G. Chinea-Pérez, J. G. Garcia-Cancel, D. Jaime Díaz, and L. A. Jaime Rivera for providing valuable assistance in field logistics, transportation, and data collection. We would also like to thank Dr. Cheryl Jefferson for the project and administrative support through the Office of Partnerships and Strategic Initiatives, Southern Research Station, USDA Forest Service (FS Agreement No.: 12-CA11330101-080). Finally, we thank the anonymous reviewers whose comments helped to improve this manuscript.

\section{Funding}

The USDA Forest Service Southern Research Station in Asheville, NC, funded this research (Award Number: 12-CA-11330101-080). Dr. Stacy A. C. Nelson from the Department of Forestry and Environmental Resources at North Carolina State University was the recipient of the awarded funds mentioned above.

\section{Availability of data and materials}

All datasets on which the conclusions of this manuscript depend on are available as supporting material in machine-readable format. 


\section{Authors' contributions}

This manuscript was developed from a chapter in the first author's (XAJ) MS thesis. He served as the principal researcher in the field, performed the data analysis, and drafted the manuscript under the support and supervision of his contributing co-authors. The second author (SJVB) contributed extensively as the primary research advisor, MS committee co-chair advisor, and project leader, in the field work logistics and manuscript revisions until completion. The third author (FHK) contributed widely as the MS committee co-chair advisor, in project development, academic advisory, and manuscript revisions until completion. The fourth author (SACN) served as the principal investigator, contributed extensively as the MS committee co-chair advisor, provided document reviews, and was the recipient of the USDA-FS funds that made this project possible. All authors read and approved the final manuscript.

\section{Ethics approval and consent to participate}

Not applicable

\section{Consent for publication}

Not applicable

\section{Competing interests}

The authors declare that they have no competing interests.

\section{Publisher's Note}

Springer Nature remains neutral with regard to jurisdictional claims in published maps and institutional affiliations.

\section{Author details}

'Department of Ecosystem Science and Management, Texas A\&M University, 2138 TAMU, College Station, TX 77843-2138, USA. ${ }^{2}$ Belle W. Baruch Institute of Coastal Ecology and Forest Science, Clemson University, PO Box 596, Georgetown, SC 29442, USA. ${ }^{3}$ USDA Forest Service, Southern Research Station, 3041 East Cornwallis Road, Research Triangle Park, NC 27709, USA. ${ }^{4}$ Center for Geospatial Analytics, Department of Forestry and Environmental Resources, North Carolina State University, Raleigh, NC 27695, USA.

\section{Received: 28 April 2017 Accepted: 27 September 2017}

\section{Published online: 20 October 2017}

\section{References}

Acevedo-Rodríguez P, Strong M (2008) Floristic richness and affinities in the West Indies. Bot Rev 74:197-207

Aho K, Derryberry D, Peterson T (2014) Model selection for ecologists: the worldviews of AIC and BIC. Ecology 95:631-636

Ammondt SA, Litton CM (2012) Competition between native Hawaiian plants and the invasive grass Megathyrsus maximus: implications of functional diversity for ecological restoration. Restor Ecol 20:638-646

Ammondt SA, Litton CM, Ellsworth LM, Leary JK (2013) Restoration of native plant communities in a Hawailian dry lowland ecosystem dominated by the invasive grass Megathyrsus maximus. Appl Veg Sci 16:29-39

Brooks ML, D'Antonio CM, Richardson DM, Grace JB, Keeley JE, Ditomaso JM, Hobbs RJ, Pellant M, Pyke D (2004) Effects of invasive alien plants on fire regimes. Bioscience 54(7):677-688

Brooks M, Lusk M (2008) Fire Management and Invasive Plants: a Handbook. United States Fish and Wildlife Service, Arlington Virginia, $27 \mathrm{pp}$

Cabin RJ, Weller SG, Lorence D, Cordell S, Hadway LJ, Montgomery R, Goo D, Urakami A (2002) Effects of light, alien grass, and native species additions on Hawaiian dry forest restoration. Ecol Appl 12(6):1595-1610

César RG, Viani RAG, Silva MC, Brancalion PHS (2014) Does a native grass (Imperata brasiliensis Trin.) limit tropical forest restoration like an alien grass (Melinis minutioflora p. Beauv.)? Trop Conserv Sci 7(4):639-656

Chinea JD (2002) Tropical forest succession on abandoned farms in the Humacao Municipality of eastern Puerto Rico. For Ecol Manag 167(1-3):195-207

Christen D, Matlack G (2006) The role of roadsides in plan invasions: a demographic approach. Conserv Biol 20:385-391

Cordell S, Sandquist DR (2008) The impact of an invasive African bunchgrass (Pennisetum setaceum) on water availability and productivity of canopy trees within a tropical dry forest in Hawaii. Funct Ecol 22:1008-1017

Cove MV, Niva LM, Jackson VL (2012) Use of probability of detection when conducting analyses of surveys of mesopredators: a case study from the Ozark Highlands of Missouri. Southwest Nat 57(3):257-261
D'Antonio CM, Vitousek PM (1992) Biological invasions, the grass-fire cycle and global change. Annu Rev Ecol Syst 23:63-87

Daehler CC (2003) Performance comparisons of co-occurring native and alien invasive plants: implications for conservation and restoration. Annu Rev Ecol Evol Systematics 34:183-211

D'Antonio CM, Meyerson LA (2002) Exotic plant species as problems and solutions in ecological restoration: a synthesis. Restor Ecol 10:703-713

Davis MA, Thompson K, Grime PJ (2005) Invasibility: the local mechanism driving community assembly and species diversity. Ecography 28(5):696-704

Didham RK, Tylianakis JM, Gemmell NJ, Rand TA, Ewers RM (2007) Interactive effects of habitat modification and species invasion on a native species decline. Trends Ecol Evol 22:489-496

Erickson HE, Davidson EA, Keller M (2002) Former land-use and tree species affect nitrogen oxide emissions from a tropical dry forest. Oecologia 130:297-308

Folke C, Carpenter S, Walker B, Scheffer M, Elmqvist T, Gunderson L, Holling CS (2004) Regime shifts, resilience, and biodiversity in ecosystem management. Ann Rev Ecol Evol Systematics 35:557-581

Francis, JK, Lowe CA; [Editors]; Trabanino S; [Translator] (2000) Silvics of native and exotic trees of Puerto Rico and the Caribbean Islands (Spanish version). General technical report IITF-GTR-15 U.S. Department of Agriculture, Forest Service International Institute of Tropical Forestry

Francis JK, Parrotta JA (2006) Vegetation response to grazing and planting of Leucaena leucocephala in a Urochloa maximum-dominated grassland in Puerto Rico. Caribb J Sci 42(1):67-74

Francisco-Ortega J, Santiago-Valentín E, Acevedo-Rodríguez P, Lewis C, Pipoly J, Meerow AW, Maunder M (2007) Seed plant genera endemic to the Caribbean Island biodiversity hotspot: a review and a molecular phylogenetic perspective. Bot Rev 73(3):183-234

Freitas SR, Hawbaker TJ, Metzger JP (2010) Effects of roads, topography, and land use on forest cover dynamics in the Brazilian Atlantic Forest. For Ecol Manag 259:410-417

Garcia-Cancel JG (2013) Effects of native and non-native grasses on woody species regeneration in a Puerto Rican subtropical dry forest. M.S. thesis. University of Puerto Rico, Mayagüez

Gooden B, French K (2014) Non-interactive effects of plant invasion and landscape modification on native communities. Divers Distrib 20:626-639

Grime JP (1979) Plant strategies and vegetation processes. John Wiley \& Sons, Chichester Griscom HP, Ashton MS (2011) Restoration of dry tropical forests in Central America: a review of pattern and process. For Ecol Manag 261:1564-1579

Hoffmann WA, Orthen B, Nascimento PKV (2003) Comparative fire ecology of tropical savanna and forest trees. Funct Ecol 17:720-726

Hoffmann WA, Adasme R, Haridasan M, Carvalho MT, Geiger EL, Pereira MAB, Gotsch SG, Franco AC (2009) Tree top kill, not mortality, governs the dynamics of savanna-forest boundaries under frequent fire in central Brazil. Ecology 90:1326-1337

Hoffmann WA, Jaconis SY, Geiger EL, Gotsch SG, Franco AC (2012) Fuels or micro climate? Understanding the drivers of fire feedbacks at savanna-forest boundaries. Aust Ecol 37:634-643

Jaime XA (2014) Forest understory regeneration after anthropogenic disturbances in a semi-deciduous tropical dry forest in Puerto Rico. M.S. thesis. North Carolina State University

Janzen DH (1988) Tropical dry forests: the most endangered major tropical ecosystem. In: Wilson EO, Peter FM (eds) Biodiversity. National Academy of Science/Smithsonian Institution, Washington DC, pp 130-137

Lockwood J, Hoopes M, Marchetti M (2007) Invasion ecology. Blackwell Publishing, Massachusetts

Lugo AE, Brandeis TJ (2005) In: Burslem DFRP, Pinard MA, Hartley SE (eds) A new mix of alien and native species coexist in Puerto Rico's landscapes, in biotic interactions in the tropics: their role in the maintenance of species diversity. Cambridge University Press, Cambridge, pp 484-509

Mack MC, D'Antonio CM (2003) Exotic grasses alter controls over soil nitrogen dynamics in a Hawaiian woodland. Ecol Appl 13(1):154-166

MacKenzie DI, Nichols JD, Royle JA, Pollock KH, Bailey LL, Hines JE (2006) Occupancy estimation and modeling. Academic Press, Burlington

Maunder M, Leiva A, Santiago-Valentín E, Stevenson DW, Acevedo-Rodrín P, Meerow AW, Mejía M, Clubbe C, Francisco-Ortega J (2008) Plant conservation in the Caribbean Island biodiversity hotspot. Bot Rev 74:197-207

Molina Colón S, Lugo AE (2006) Recovery of a subtropical dry forest after the abandonment of different land uses. Biotropica 38(3):354-364

Molina Colón S, Lugo AE, Ramos González OM (2011) Novel dry forests in southwestern Puerto Rico. For Ecol Manag 262:170-177 
Monsegur-Rivera O (2009) Vascular flora of the Guánica dry forest. In: M.S. thesis University of Puerto Rico, Mayagüez

Murphy PG, Lugo AE (1986) Structure and biomass of a subtropical dry forest in Puerto Rico. Biotropica 18:89-96

Murphy PG, Lugo AE (1995) Dry forests of Central America and Caribbean islands. In: Bullock SH, Mooney HA, Medina E (eds) Seasonally dry tropical forests. Cambridge University Press, New York, pp 9-34

O'Brien RM (2007) A caution regarding rules of thumb for variance inflation factors. Quality Quantity 41:673-690

Padmanaba M, Sheil D (2014) Spread of the invasive alien species Piper aduncum via logging roads in Borneo. Trop Conserv Sci 7(1):35-44

Pan W (2001) Akaike's information criterion in generalized estimating equations. Biometrics 57:120-125

Parrotta JA (2000) Leucaena leucocephala (Lam.) de Wit. Leguminosae (Mimosoideae). In: Francis JK, Lowe CA (eds) Silviculture of native and exotic trees of Puerto Rico and the Caribbean islands. USDA Forest Service, International Institute of Tropical Forestry, Gen.Tech. Rep. IITF-15, Río Piedras, pp 306-316

Pérez Martínez FO (2007) Effect of an exotic canopy on understory species composition in degraded subtropical dry forest of Puerto Rico. In: M.S. thesis. University of Puerto Rico, Mayagüez

Pivello VR, Carvalho VMC, Lopes PF, Peccinini AA, Rosso S (1999) Abundance and distribution of native and alien grasses in a 'Cerrado' (Brazilian savanna) biological reserve. Biotropica, 31, 71-82

R Core Team (2014) R: a language and environment for statistical computing. $R$ Foundation for Statistical Computing, Vienna http://www.R-project.org/

Ramjohn IA, Murphy PG, Burton TM, Lugo AE (2012) Survival and rebound of Antillean dry forests: role of forest fragments. For Ecol Manag 284:124-132

Rew $L$, Johnson MP (2010) Reviewing the role of wildfire on the occurrence and spread of invasive plant species in wildland areas of the intermountain western United States. Invasive Plant Sci Manage 3(4):347-364

Richardson DM, Pyšek P, Rejmánek M, Barbour MG, Panetta FD, West CJ (2000) Naturalization and invasion of alien plants: concepts and definitions. Divers Distrib 6:93-107

Rojas-Sandoval J, Acevedo-Rodríguez P (2014) Naturalization and invasion of alien plants in Puerto Rico and the Virgin Islands. Biol Invasions 17(1):149-163

Sanchez-Azofeifa GA, Kalacska M, Quesada M, Calvo-Alvarado JC, Nassar JM, Rodríguez JP (2005) Need for integrated research for a sustainable future in tropical dry forests. Conserv Biol 19:285-286

Santiago Garcia RJ, Molina Colón S, Sollins P, Van Bloem SJ (2008) The role of nurse trees in mitigating fire effects on tropical dry forest restoration: a case study. Ambio 37:604-608

Thaxton JM, Cordell S, Cabin RJ, Sandquist DR (2012a) Non-native grass removal and shade increase soil moisture and seedling performance during Hawaiian dry forest restoration. Restor Ecol 20:475-482

Thaxton JM, Van Bloem SJ, Whitmire SL (2012b) Fuel conditions associated with native and exotic grasses in a subtropical dry forest in Puerto Rico. Fire Ecol 8(3):9-17

Van Bloem SJ, Murphy PG, Lugo AE (2003) Subtropical dry forest trees with no apparent damage sprout following a hurricane. Trop Ecol 44(2):137-145

Van Bloem SJ, Lugo AE, Murphy PG (2004) Tropical dry forests. Elsevier Ltd., pp 1-10

Van Bloem SJ, Murphy PG, Lugo AE, Ostertag R, Rivera Costa M, Ruiz Bernard I, Molina Colón S, Canals Mora M (2005) The influence of hurricane winds on Caribbean dry forest structure and nutrient pools. Biotropica 37(4):571-583

Van Bloem SJ, Murphy PG, Lugo AE (2007) A link between hurricane-induced tree sprouting, high stem density and short canopy in tropical dry forest. Tree Physiol 27:475-480

Veldman JW, Putz FE (2010) Long-distance dispersal of invasive grasses by logging vehicles in a tropical dry Forest. Biotropica 42(6):697-703

Veldman JW, Putz FE (2011) Grass-dominated vegetation, not species-diverse natural savanna, replaces degraded tropical forests on the southern edge of the Amazon Basin. Biol Conserv 144:1419-1429

Vieira DLM, Scariot A (2006) Principles of natural regeneration of tropical dry forests for restoration. Restor Ecol 14(1):11-20

Vitousek PM, D'Antonio CM, Loope LL, Westbrooks R (1996) Biological invasions as global environmental change. Am Sci 84:468-478

Von der Lippe M, Kowarik I (2007) Long-distance dispersal of plants by vehicles as a driver of plant invasions. Conserv Biol 21:986-996

Wilcove DS, Rothstein D, Dubow J, Phillips A, Losos E (1998) Quantifying threats to imperiled species in the United States. Bioscience 48:607-615

Wolfe BT (2008) Post-fire regeneration in subtropical dry Forest of Puerto Rico. M. S. thesis. University of Puerto Rico, Mayagüez
Wolfe BT, Van Bloem SJ (2012) Subtropical dry forest regeneration in grassinvaded areas of Puerto Rico: understanding why Leucaena leucocephala dominates and native species fail. For Ecol Manag 267:253-261

Wolfe BT, Saldaña Diaz GE, Van Bloem SJ (2014) Fire resistance in a Caribbean dry forest: inferences from the allometry of bark thickness. J Trop Ecol 30(02):133-142

\section{Submit your manuscript to a SpringerOpen ${ }^{\circ}$ journal and benefit from:}

- Convenient online submission

- Rigorous peer review

- Open access: articles freely available online

- High visibility within the field

- Retaining the copyright to your article

Submit your next manuscript at $\boldsymbol{\nabla}$ springeropen.com 